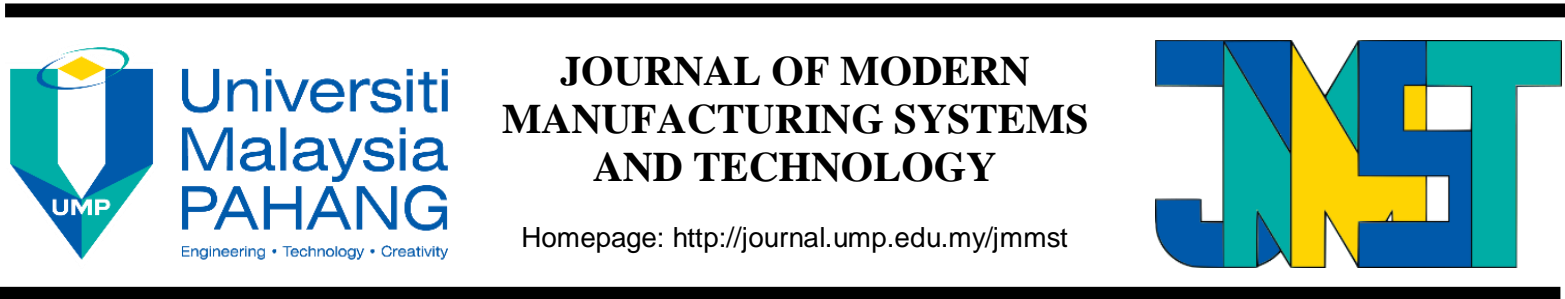

\title{
PERFORMANCE MEASUREMENT ANALYSIS USING SWOT AND BALANCED SCORECARD METHODS
}

\author{
Shafira Putri Ramadhani ${ }^{1}$, Qurtubi $^{1}$, M Ragil Suryoputro $^{1}$, Wahyudhi Sutrisno ${ }^{1}$
}

\begin{tabular}{|c|c|}
\hline *Correspondence & ABSTRACT \\
\hline $\begin{array}{l}\text { qurtubi@uii.ac.id } \\
{ }^{1} \text { Department of Industrial } \\
\text { Engineering, Universitas } \\
\text { Islam Indonesia, Yogyakarta, } \\
\text { Indonesia }\end{array}$ & $\begin{array}{l}\text { CV. XYZ is a company engaged in goat farming and goat milk processing which is developing } \\
\text { to place itself in the industry today. To place companies in the industrial world must know } \\
\text { the level of performance and strategies needed. One method that can be used is SWOT and } \\
\text { the balanced scorecard methods. For the SWOT results, the company is in quadrant I, which }\end{array}$ \\
\hline $\begin{array}{l}\text { Articles Info: } \\
\text { Received } 17 \text { June } \mathbf{2 0 1 9} \\
\text { Received in revised form } \\
\mathbf{1 7} \text { July } 2019 \\
\text { Accepted } 29 \text { September } \\
\mathbf{2 0 1 9} \\
\text { Available Online } 30 \\
\text { September } 2019\end{array}$ & $\begin{array}{l}\text { means that the company is very profitable because the company has internal power to take } \\
\text { advantage of opportunities that exist in the external environment. Then for balanced } \\
\text { scorecard results, the first financial perspective: the average net profit margin is } 42.31 \% \text {, } \\
\text { the average ROA is } 6.91 \% \text {, the average ATO is } 15.85 \% \text {, and the average operating ratio is } \\
1.043 \text {. All measures in the financial perspective have reached the target. Strategic measure } \\
\text { in the customer's perspective: the level of customer satisfaction is } 77.58 \% \text { which has } \\
\text { reached the target and customer acquisition an average of } 3.49 \% \text { which has not reached }\end{array}$ \\
\hline $\begin{array}{l}\text { Keywords: } \\
\text { SWOT, } \\
\text { Balanced Scorecard, } \\
\text { Strategic, } \\
\text { Performance } \\
\text { Measurement }\end{array}$ & $\begin{array}{l}\text { the target. Strategic measure internal business process perspective: promotion intensity, } \\
\text { product innovation, after-sales service, and production efficiency that has reached the } \\
\text { target. Strategic measure of growth and learning perspective using: employee satisfaction } \\
\text { level of } 85.69 \% \text {, average employee retention of } 14.64 \% \text {, and average employee productivity } \\
\text { of } 5.05 \% \text {. Strategic measures in the perspective of growth and learning cannot reach the } \\
\text { targets of the company. Based on the overall calculation on the company, the performance } \\
\text { rating scale is } 0.20 \text { and is included in the fairly good category. }\end{array}$ \\
\hline
\end{tabular}

\section{INTRODUCTION}

Today's competition is getting tougher and technological developments are increas-ing, making companies must determine the best strategy in managing the business. Therefore, a method is needed to measure the performance of the company as a way for the company to know the strategies and targets that have been determined can be achieved. One of method that can be used in performance measurement is the Balanced Scorecard (BSC). The balanced scorecard was introduced by David P. Norton and Robert Kaplan in 1990 in the United States in a study of performance measurement in a company [3]. The balanced scorecard is a concept of performance measurement that is used to balance between two sides, financial and non-financial. There are four perspectives in balanced scorecard: financial perspective, customer perspective, internal business perspective, and growth and learning perspective [2]. For companies that are classified as young, a performance measurement system is needed with the aim of improving the prosperity of the company in the future [1]. Before measuring with the balanced scorecard method, strategy analysis is needed first and can be done with a SWOT analysis. The use of SWOT analysis can maximize strengths and opportunities, minimize weaknesses and threats for the company [7]. SWOT is an 
approach taken sequentially in identifying strengths and weaknesses in the company's internal and opportunities and threats in the external company. The use of balanced scorecard and SWOT aims to realize the company's vision and mission which can make it easier to identify the weaknesses of the company through measuring its performance so that it can obtain strategic balance between targets of financial performance, customer performance, internal process performance and HR performance [5].

$\mathrm{CV}$. XYZ is a company engaged in goat farming and goat milk processing which is developing to place itself in the industry today. To place companies in the industrial world must know the level of performance and strategies needed. For now, the company has a vision and mission but does not yet have the performance strategy or benchmarks needed to evaluate the company's performance. Therefore, to achieve the objectives of the company, measurements are needed to assess how much the performance of the company is and then the appropriate strategy recommendations from the measurement results will be known. By using the SWOT method as a company condition translator tool and the balanced scorecard as a strategy translator tool to become a strategic measure, the results of performance measurement and proposed strategies will be obtained to achieve company goals.

\section{METHODOLOGY} methods.

The following is about data sources, data collection techniques, and SWOT Balanced Scorecard

\section{Data Collection Techniques}

This data collection technique with literature studies, observations, interviews, questionnaires, company historical data. For literature studies it is used to identify theories needed in research such as journals, books, and files that are related to the topic of research. Observation is used as an initial field study of research by visiting the research site directly. Interviews are used to collect data needed in research conducted with question and answer by researchers and company sources. This interview contains SWOT (strength, weakness, opportunity, threat) which is used as input into the four balanced scorecard perspectives. Steps to interview experts, give questions to experts, then write expert answers which will then be used in the next method. Questionnaires are used for data collection by giving statement questionnaires that are suitable with the research objectives. The questionnaire in this study was the customer satisfaction questionnaire and employee satisfaction questionnaire.

\section{SWOT and Balanced Scorecard Methods}

SWOT analysis is a useful tool for planning a strategy in environmental management, and making a basic foundation for identifying situations and designing future procedures needed in strategic attitudes. The balanced scorecard is one of the most effective tools for evaluating sustainability performance in the strategic objectives of the organization that makes it possible to monitor and measure organizational progress, both by adding social and economic perspectives in each balanced scorecard perspective [6]. SWOT balanced scorecard is a simple concept of two tools that are combined into a tool that has the potential to identify strategic factors in the company [4].

\section{RESULT AND DISCUSSION}

On this section the results of the SWOT and the results of measuring company per-formance with the balanced scorecard.

\section{SWOT}

To determine the company's strategy design, data is needed regarding the company's internal and external conditions. This swot is obtained from the results of interviews with company experts. 
Table 1. Strengths \& Weaknesses

\begin{tabular}{|c|c|c|c|}
\hline No & Strength & No & Weakness \\
\hline 1. & $\begin{array}{l}\text { Environmental cleanliness } \\
\text { (Application of } 5 \mathrm{~S} \text { ) }\end{array}$ & 1. & $\begin{array}{c}\text { Don't have permission } \\
\text { (BPOM) }\end{array}$ \\
\hline 2. & Product quality & 2. & Website not available \\
\hline 3. & Selected raw materials & 3. & $\begin{array}{c}\text { Human resources are not } \\
\text { enough }\end{array}$ \\
\hline 4. & Choice of flavors & 4. & $\begin{array}{c}\text { Manual financial } \\
\text { calculations }\end{array}$ \\
\hline 5. & Health benefits & 5. & Lack of use of technology \\
\hline 6. & Have your own farm & 6. & Lack of application of SOP \\
\hline 7. & Milk identity & & \\
\hline 8. & $\begin{array}{l}\text { The product has no side } \\
\text { effects }\end{array}$ & & \\
\hline 9. & $\begin{array}{l}\text { Processing of goat's own } \\
\text { milk }\end{array}$ & & \\
\hline
\end{tabular}

Table 2. Opportunities \& Threats

\begin{tabular}{clll}
\hline No & \multicolumn{1}{c}{ Opportunity } & No & \multicolumn{1}{c}{ Threat } \\
\hline 1. & Online media as a promotion & 1. & $\begin{array}{l}\text { The location is close to the } \\
\text { volcano }\end{array}$ \\
2. & $\begin{array}{l}\text { Sponsor for children's } \\
\text { competitions }\end{array}$ & 2. & $\begin{array}{l}\text { There are many } \\
\text { competitors around }\end{array}$ \\
3. & & $\begin{array}{l}\text { Awareness of consuming } \\
\text { goat's milk }\end{array}$ \\
4. & $\begin{array}{l}\text { New knowledge about goat's } \\
\text { milk }\end{array}$ \\
5. & $\begin{array}{l}\text { Liquid milk products are } \\
\text { processed into milk powder } \\
\text { and candy }\end{array}$ \\
6. Provide tour area services
\end{tabular}

The tables above show that SWOT is able to identify internal and external conditions of the company compared to competitors. The use of SWOT aims to analyze the condition of the company which later with SWOT can provide the best corporate strategy design. And then, SWOT analysis results with two factors that influence IFAS (Internal) and EFAS (External).

Table 3. IFAS and EFAS Factors

\begin{tabular}{lr}
\hline \multicolumn{2}{c}{ IFAS Factor } \\
\hline Strength & 2.181 \\
Weakness & 1.108 \\
S-W & $\mathbf{1 . 0 7 2}$ \\
\hline
\end{tabular}

\begin{tabular}{cc}
\hline \multicolumn{2}{c}{ EFAS Factor } \\
\hline Opportunity & 2.321 \\
Threat & 0.571 \\
O-T & $\mathbf{1 . 7 5 0}$ \\
\hline
\end{tabular}

From the results of the weights of IFAS and EFAS factors that have been calculated and then included in the SWOT analysis diagram. 


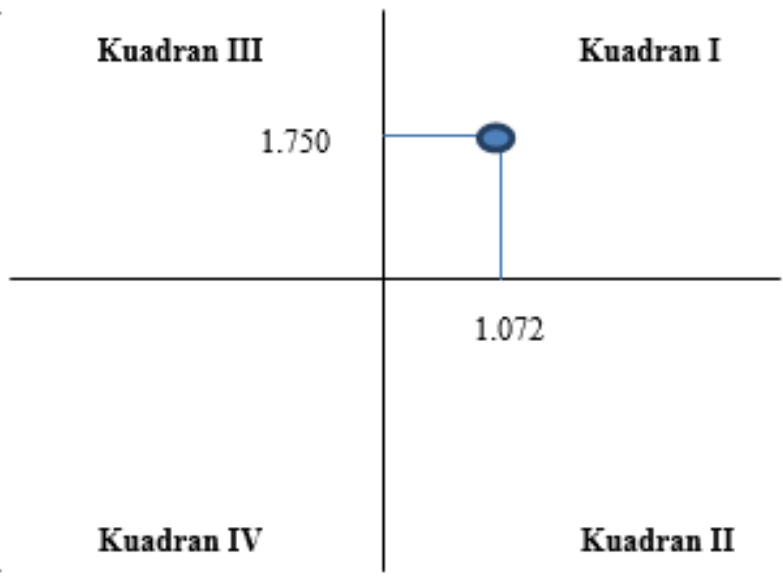

Fig. 1. SWOT Analysis Diagram

Based on the Fig. 1 above, it can be seen that the SW difference and the OT difference meet at one point in quadrant I. Located in quadrant I means that the company's position is very profitable, with that position the company can take advantage of strengths and opportunities for growth more aggressive.

\section{Balanced Scorecard}

Scoring based on balanced scorecard measurements according to the results of the comparison between company targets and the percentage of average realization.

Table 4. Balanced Scorecard Results

\begin{tabular}{|c|c|c|c|c|}
\hline Perspective & Strategic Size & Target & $\begin{array}{l}\text { Average } \\
\text { Realization }\end{array}$ & Score \\
\hline \multirow{4}{*}{ Fiinancial } & NPM & $40 \%$ & $42,31 \%$ & 1 \\
\hline & ROA & $5 \%$ & $6,91 \%$ & 1 \\
\hline & ATO & $15 \%$ & $15,85 \%$ & 1 \\
\hline & Operating ratio & 1 & 1,043 & 1 \\
\hline \multirow{2}{*}{ Customer } & $\begin{array}{l}\text { Customer } \\
\text { satisfaction }\end{array}$ & $70 \%$ & $77,58 \%$ & 1 \\
\hline & $\begin{array}{l}\text { Customer } \\
\text { acquisition }\end{array}$ & $5 \%$ & $3,49 \%$ & -1 \\
\hline \multirow{4}{*}{$\begin{array}{l}\text { Internal } \\
\text { Business } \\
\text { Process }\end{array}$} & $\begin{array}{l}\text { Intensity of } \\
\text { promotion }\end{array}$ & - & - & - \\
\hline & $\begin{array}{l}\text { Product } \\
\text { innovation }\end{array}$ & - & - & - \\
\hline & After-sales service & - & - & - \\
\hline & Efisiensi Produksi & $75 \%$ & $81,25 \%$ & 1 \\
\hline \multirow{3}{*}{$\begin{array}{l}\text { Growth and } \\
\text { Learning }\end{array}$} & $\begin{array}{l}\text { Employee } \\
\text { satisfaction }\end{array}$ & $100 \%$ & $85,69 \%$ & -1 \\
\hline & $\begin{array}{l}\text { Employee } \\
\text { retention }\end{array}$ & $10 \%$ & $14,64 \%$ & -1 \\
\hline & $\begin{array}{l}\text { Employee } \\
\text { productivity }\end{array}$ & $10 \%$ & $5,05 \%$ & -1 \\
\hline
\end{tabular}

Based on the table 7 above, the growth that occurs in each perspective is measured by a positive value which means there is an increase and a negative value which means a decline and a zero value means that it remains. 
The results of all the balanced scorecard perspectives used are a total score of 2 perspectives used in the balanced scorecard of 10 sizes. With the number of scores and number of sizes, the results obtained are 0.20 . This is a performance rating scale.

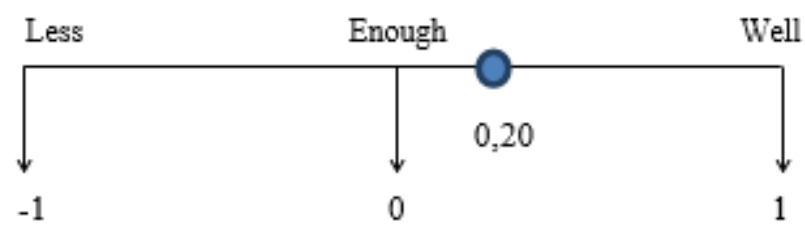

Fig. 2. Performance Rating Scale

From Fig. 2 above shows that the company is included in a sufficient category which means that the performance of the company is good but needs to be increased again especially in the part of the growth and learning perspective.

\section{CONCLUSION}

From the results of the above research, the performance of the company included in the sufficient category based on the performance rating scale with a rating of 0,20 and the number of scores from all the balanced scorecard perspectives is 2 . Furthermore, for a strategy that is in accordance with the SWOT company is a growth strategy that the strategy utilizes the company's internal strength to get opportunities that exist in the external environment in order to increase the company's growth.

\section{REFERENCES}

[1] Bititci, U. C. International Journal of Operations \& Production Management. Integrated Performance Measurement System : A Development Guide (1997).

[2] Kaplan, R. S., \& Norton, D. P. Translating Strategy Into Action The Balanced Scorecard. Jakarta: Erlangga (1996).

[3] Koesomowidjojo, S. R. Balanced Scorecard: An Organizational Performance Measurement Model with Four Perspectives. Jakarta: Raih Asa Sukses (2017).

[4] Novanda, D. Journal of Industrial Engineering, Andalas University, Padang. Implementation of SWOT Balanced Scorecard Integration in Designing Performance Measurement Systems (2014).

[5] Rangkuti, F. SWOT Balanced Scorecard. Jakarta: PT. Gramedia Pustaka Utama (2011).

[6] Schaltegger, H. Journal Business Ethics. The Sustainability Balanced Scorecard : A Systematic Review of Architectures (2016).

[7] Sutanto, Y., et. al. Information Technology Journal. Analysis of Value Innovation as a Corporate Strategy Design at STMIK AMIKOM Yogyakarta (2013). 